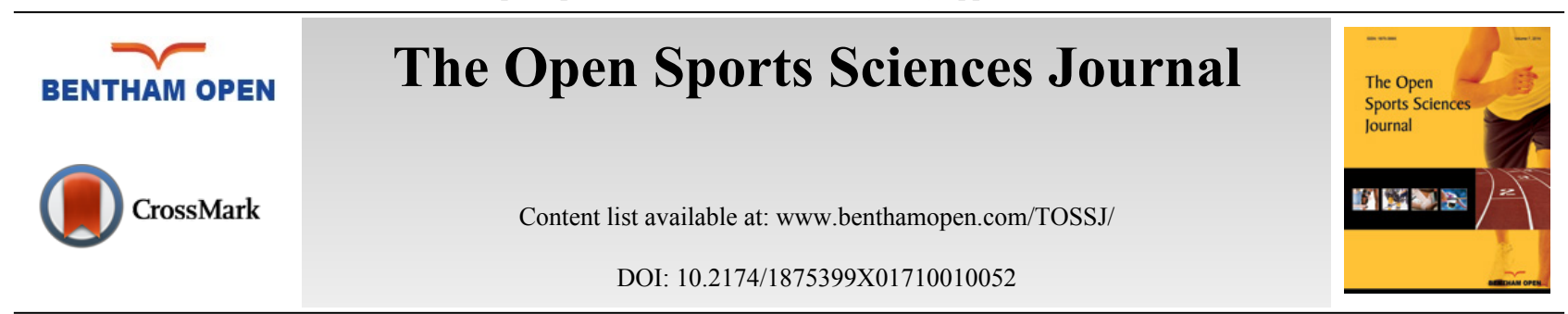

REVIEW ARTICLE

\title{
Fatigue and Recovery in Soccer: Evidence and Challenges
}

Diego Marqués-Jiménez ${ }^{1, *}$, Julio Calleja-González ${ }^{1}$, Iñaki Arratibel ${ }^{1}$, Anne Delextrat ${ }^{2}$ and Nicolás Terrados ${ }^{3,4}$

${ }^{I}$ Physical Education and Sport Department, University of Basque Country (UPV-EHU), Vitoria-Gasteiz, Spain

${ }^{2}$ Sport and Health Sciences Department, Oxford Brookes University, Oxford, UK

${ }^{3}$ Department of Functional Biology, University of Oviedo, Oviedo, Spain

${ }^{4}$ Regional Unit of Sports Medicine of Asturias, Aviles, Spain

Received: July 20, 2016

Revised: October 15, 2016

Accepted: November 10, 2016

\section{Abstract:}

\section{Background:}

Soccer presents physiological, metabolic, physical and psychological demands which can deteriorate players' performance due to fatigue. The high variability in physiological, metabolic, physical and psychological responses also influences the magnitude of exercise-induced muscle damage, with symptoms negatively affecting neuromuscular function during recovery or subsequent training sessions or matches. Consequently, more precise and consistent knowledge is required in this area to optimize training and performance.

\section{Objective:}

Therefore, the purpose is to sum-up current evidence on fatigue and recovery in soccer players, to shed light on factors that can affect players' performance, and to suggest applications for coaches and further research.

\section{Method:}

A comprehensive review of the scientific literature on the field was conducted.

\section{Results:}

Physical performance decrements during matches have traditionally been associated with physiological fatigue, but the magnitude of the symptoms in soccer players is unclear and depends on several factors. Moreover, the decline in physical performance during a soccer match is related to specific demands of each match. These could explain inter-individual variability in acute fatigue or training recovery processes when comparing players from the same team. Recovery counteracts the effects of fatigue, both peripheral and central, but there is a lack of consensus about the usefulness of tests used to monitor fatigue and recovery kinetics.

\section{Conclusion:}

Although fatigue and recovery in soccer has been extensively studied, there are still uncertainties about the underlying mechanisms because they are influenced by physiological and match-related demands.

Keywords: Football, Markers, Metabolism, Physiology, Stress, Training.

\section{INTRODUCTION}

Soccer players are exposed to mechanical and metabolic stress which might induce physiological changes. Game

\footnotetext{
* Address correspondence to this author at the Faculty of Physical Activity and Sport Sciences, University of Basque Country (UPV-EHU) Physical Education and Sport Department - Faculty of Physical Activity and Sport Sciences (UPV-EHU), Portal de Lasarte, 71, 01007, Vitoria-Gasteiz, Spain; Tel: 0034 6660275738; E-mail: dmarques001@ikasle.ehu.eus
} 
demands include accelerations, decelerations, jumps, changes of direction, technical and tactical skills to successfully adapt to a rapidly changing environment and achieve optimal performance [1]. There is sometimes a decrease in performance: participation in a single match leads to acute and residual fatigue, characterized by a decline in physical performance over the following hours and days [2]. Fatigue can be described as the inability to maintain a given exercise intensity or power output level [3], although it is usually defined as any reduction in physical or mental performance $[4,5]$. The physical demands imposed on soccer players have been widely reported [6 - 8], but some performance indicators (e.g. total distance covered) represent an inaccurate estimation of the overall physical requirements and the readiness to perform maximally.

Game demands have an eccentric component with a potential exercise-induced muscle damage (EIMD) [1], so the magnitude of EIMD and other physiological alterations elicited by match play are also associated with specific movement demands [9]. Together with a decline in performance, long-term muscle damage and increased levels of intramuscular enzymes and inflammatory markers are reported following soccer competition [9]. There is therefore a relation between EIMD and fatigue: muscle fatigue may partly derive from EIMD [10]. Anyway, soccer players can be fatigued without EIMD symptoms and vice versa.

Recovery counteracts the effects of fatigue, both peripheral and central, and can be defined as the ability to meet or exceed performance in a particular activity [11]. In soccer, the ability to recover from intense training or match is a key aspect of performance $[12,13]$ : those who recover faster will have a greater advantage [14]. To ensure adequate recovery after soccer matches and training sessions, it is necessary to know the type of fatigue induced and, if possible, its underlying mechanisms $[15,16]$. Although there is no consensus on a central strategy for recovery, routine assessments of fatigue and recovery are therefore insightful efforts to ensure that players successfully adapt to training and competition stress and to evaluate athletes' readiness for return to competition [17].

\section{EVIDENCE, MECHANISMS AND CAUSES OF FATIGUE IN SOCCER}

Physical performance decrements during matches have traditionally been associated with physiological fatigue [8, 18], but there are different situational variables or contextual factors which can also influence players' physical performance (explained below). Thus interpreting match-related fatigue is highly complex, although is it clear that fatigue occurs towards the end of matches as well as temporarily during the game, independently of the competitive standard and playing position [19].

Running performance has been deeply analyzed as a fatigue indicator. It has been shown that the distance covered by players can be lower in the second half than in the first half of a game (18\% lower) regardless of playing position [20]. In addition, the distance covered performing high-intensity activities can be $20 \%$ lower in the last 15 minutes than in the first 15 minutes of the match, regardless of playing position [7]. Furthermore, the total distance covered at different intensities in the first half can significantly influence the distances covered in the second half [8] and can have a significant impact on the recovery immediately following the most intense 5-min periods of the second half [21]. It has been found that there may be a similar difference between the distance covered performing high-intensity running with $(148 \pm 78 \mathrm{~m}$ vs. $193 \pm 9 \mathrm{~m}, \mathrm{p}<0.01)$ and without ball possession $(229 \pm 85 \mathrm{~m}$ vs. $278 \pm 97 \mathrm{~m}, \mathrm{p}<0.01)$ between the first 15 min and last 15-min period of the game [7]. Fatigue may also be evidenced by the increased duration of low-intensity activities [22]. Mean recovery time between very high-intensity running bouts can be about $72 \mathrm{~s}$, with a $28 \%$ longer recovery time during the last 15 minutes than the first 15 minutes of the game $(83 \pm 26 \mathrm{~s} v \mathrm{~s} .65 \pm 20 \mathrm{~s}, \mathrm{p}<0.01)$ [7]. The decline in high-intensity running immediately after the most intense 5-min period can be around $8 \%$ [6], and greater in attackers and central defenders, compared to other playing positions [7].

The appropriateness of the commonly used measures of high-speed activity for determining variability in an elite soccer team is debatable. For future research individualization of high-speed running thresholds according to fitness characteristics might be a better indicator of running performance and fatigue occurrence [23]. Additionally, no mean decrement in maximal sprinting speed has been observed during bouts (a minimum of three consecutive sprints with a recovery duration $<30 \mathrm{~s}$ separating efforts) when up to five consecutive sprints were analyzed, suggesting that considering shorter accelerations could give a greater insight in game-specific situations [24].

Physical performance measurements have also been used as indicators of fatigue, mainly jumping and sprinting performance. Immediately after a 90-min game, fatigue can be evidenced by a reduction of sprint $(-3 \%, \mathrm{p}<0.001)$ [4, 12] and jumping performance $(-4.4 \pm 0.8 \%)$ [12]. These decrements are linked to the players' profile of soccer activity $[25,26]$. Although physical performance declines over the course of a soccer match, it seems that players can be able to 
maintain their technical abilities in the face of physical fatigue or they adapt a pacing strategy that prevent their skill performance from suffering [27].

The mechanisms that reduce the ability to perform maximally are not exactly understood. It seems that after shortterm high-intensity periods in both halves, fatigue is related to disturbances in ion homeostasis within the muscle cell and an impaired excitation of the sarcolemma. In the initial phase of the second half fatigue is linked to lower muscle temperatures compared with the end of the first half, and towards the end of the game fatigue seems likely to be caused by low glycogen concentrations [18]. Fatigue following a soccer match is multifactorial and mainly related to dehydration, glycogen depletion, EIMD and central fatigue [28].

The development of temporary fatigue during high intensity exercise is related to an accumulation of potassium in the muscle interstitium, and not causally linked to high muscle lactate, high muscle acidosis or low muscle creatine phosphate [18]. The accumulation of extracellular potassium can impair the excitation of the sarcolemma (depolarize the muscle membrane potential) and reduce force development [18].

Strength and power decrements towards the end of the game reflect the depletion of glycogen stores in active muscles. In favor of this hypothesis, it was observed in Swedish soccer players that those with a low glycogen content in the vastus lateralis muscle covered $25 \%$ less overall distance than the other players [29]. Although muscle glycogen stores are not always totally depleted by the end of a soccer game, large depletion of muscle glycogen have been found [25, 30 - 32], but they depend on inter-individual differences, such as motivation, physical ability, playing position, etc. Decreases in glycolytic capacity and muscle glycogen are associated with a reduction in blood lactate concentration ([La]) in the second half with respect to the first half, and with the lower distance covered and lower intensity of efforts during the game $[19,33,34]$. The decreased [La] and increased plasma free fatty acid concentrations have been interpreted as a change in the choice of energy substrates [31, 35, 36]. More specifically, changes in the quality and quantity of activities during the last minutes of the game suggest an alteration in the physical capacity of soccer players.

Dehydration and hyperthermia have been suggested as being potentially responsible for acute fatigue in soccer [37]. Soccer players have been reported to lose up to 3 liters of fluid during games in temperate thermal environments and as much as 4-5 liters in hot and humid environments [35, 37], and these are linked to decreases in physical performance. Indeed, a significant correlation $(\mathrm{r}=0.73 ; \mathrm{p}<0.05)$ was reported between net fluid loss during the match and fatigue index in a post-match sprint test [38]. In addition, it has been observed that cognitive function is better maintained during 90 minutes of continuous exercise when fluid is supplied to players [39]. Furthermore, a body mass loss of 1-2\% can contribute to hyperthermia [40]. During a soccer game, the average core temperature ranges between 39.0 and $39.5^{\circ} \mathrm{C}[18,41]$ whereas muscle temperature has previously been shown to be $0.5-1^{\circ} \mathrm{C}$ lower [42]. The hyperthermic state may accelerate the degradation of purine nucleotides and/or catabolism of amino acids with concomitant hyperammonemia, which has been linked to central fatigue [43, 44].

Traditionally, there is relatively little scientific information about the effect of central fatigue on soccer performance. Central fatigue could also be an inherent factor in the game, being important towards the end of the game and linked to the deterioration in physical capacity. It is obvious that central fatigue deteriorates technical performance [45], accuracy and decision-making speed [46], but there is no scientific consensus regarding what is the effect of central fatigue on physical performance $[4,45,47]$. As a consequence, more research is needed to clarify the impact of central fatigue on soccer-specific physical performance.

The physical demands of soccer can induce EIMD [2, 48], leading to strength and power decrements [49 - 51], increased levels of intramuscular enzymes [2, 50 - 56], a marked inflammatory response [2, 50, 55, 57, 58] and associated upregulated oxidative stress $[2,48,54,59,60]$ during recovery. The magnitude of EIMD can vary among athletes, and is greater when a player is not accustomed to the required activity [60, 61], such as in pre-season, transition between seasons, or during the recovery period from an injury. The resulting structural changes may impair physical performance during the hours and days following the match so it is likely a major factor to consider in an attempt to explain post-soccer match fatigue [61]. Anyway, more research is needed because it has also been suggested that running performance is unaffected over prolonged periods of fixture congestion despite the evidence of EIMD combined with a decline in physical performance up to $72 \mathrm{~h}$ post-match [62].

Hormonal responses and their relationship to immune function in soccer players have also been associated with fatigue. Soccer matches can cause hormonal stress that induces an increase of substances that can influence leukocytes function, in particular their numerical and functional capacity may be reduced after intense exercise [63 - 65]. Although such responses to soccer training and competition do not appear to be pronounced, variations in immune cell numbers 
and function are reported in professional soccer players over the course of a season and could influence soccer players' performance [63].

Therefore, physiological fatigue is determined by a combination of central (concerned with the descending motor pathways from the brain and spinal cord, which regulate the activity of the muscle cell and energy production) and peripherals (described as impairment within the active muscle) factors [4, 5], and can be higher in a hot and humid environment [38]. The underlying physiological mechanisms of each type of fatigue influence both physical and technical performance, but it seems that physical performance is affected in a greater extent by peripheral fatigue whereas technical performance is influenced by central factors. Anyway, fatigue in soccer players could also be attributed to a combination of contextual factors.

\section{SITUATIONAL VARIABLES IN MATCH-RELATED FATIGUE IN SOCCER PLAYERS}

The decline in physical performance during a soccer match is not only a direct consequence of physiological fatigue. It seems that professional soccer players regulate their physical efforts according to the specific demands of each game and periods of the game, thus situational variables should be taken into account in soccer performance analysis [22]. It has been suggested that individual activity profiles are highly variable and include elements of selfpacing, because decision making about opportunities to become engaged in play dictates individual activities [66]. In addition, increased player density and congestion, increased intensity of play, and longer stoppage breaks that allow greater player recovery and subsequently more intense play, all determine physical responses of soccer players [67].

The work rate of players can be influenced by the activity profile of opponents. One possible reason could be repetitive pressure from the opposition on an individual player, leading to an incapacity to act in response to game demands $[68,69]$. It has also been showed that the total distance covered and extent of high-intensity running during matches can be lower against "weaker" opponent teams than against "better" $[8,70,71]$. Soccer tactics and formation do not influence the activity profiles of players, except for attackers, but affects very-high-intensity running and some technical skills [72]. Physical and technical demands are also influenced by positional interchanges, but players who commonly transition between positions seem able to adapt to these switches [73]. Other factors such as the introduction of substitutes can influence high-intensity running. Indeed, substitutes could cover $15 \%$ more distance $(p<0.01)$ performing high-intensity running for a given time period of a match compared to a player who is on the pitch for the entire match [6]. The score-line could also influence physical performance of the team and individual players [74]. It has been confirmed that players perform significantly less high-intensity actions when winning than when losing or when the score is level, because when losing, players are more likely to produce maximal efforts in order to come back in the match $[70,75,76]$. Match location seems to influence the work rate of soccer players too [74]. Some studies showed that home teams cover greater distances than away teams during low-intensity activity [68, 69, 71], but other studies suggest that this parameter is linked to other situational variables (e.g. playing at home and losing against a weak opponent) [75]. The causes of other factors (such as travel effects, referee bias, territoriality, crowd effects, specific tactics, rule factors, and psychological factors) and the way in which they affect performance are still not clear [77].

In conclusion, it is complicated to evaluate the influence of fatigue on the physical performance of soccer players without considering the independent and interactive effects of situational variables related to tactical and strategic factors. Therefore, physical performance should be analyzed according to the situational variables relevant to each game $[78,79]$.

\section{RECOVERY IN SOCCER}

Understanding the physiological concept of recovery is essential to avoid the detrimental effects of overtraining. Overall, the recovery process has essentially three phases: immediate recovery (which occurs within a set of exercise, between efforts), short-term recovery (between sets of exercise or interval work bouts), and training recovery (between successive work-outs or competitions) [11]. Immediate and short-term recoveries are linked to metabolic, energy sources and electrolytes regeneration, whereas training recovery is linked to structural and energy sources restoration. In the context of soccer matches or training sessions, these physiological responses are highly variable and depend on several intrinsic factors [1], but they are also influenced by extrinsic factors such as training status, age, gender and muscle fiber type $[80,81]$. These could explain inter-individual variability in acute fatigue or training recovery processes when comparing players from the same team.

The activity of most elite soccer players during the competitive season entails 1-week cycles of training, taper, 
competition and recovery from one week to the next [52]. Furthermore, players from top clubs may have additional commitments such as other cup matches or representing their country in international competitions. In some cases, elite players can have two or three games in just seven days. These competitive demands may impose strains on various physiological systems $[64,82]$, and can also influence the amount of time needed to achieve complete recovery after a match [83].

Soccer players usually need 48-72 hours to restore metabolic homeostasis, muscle trauma and anaerobic performance decrements [2, 51, 83], although several improvements have been demonstrated 24 hours post-match [25]. Nevertheless, post-game performance recovery and inflammatory adaptations in response to a three-game weekly microcycle (Sunday, Wednesday and Sunday) displayed a different response pattern, with strong indications of greater physiological stress and fatigue after the middle game that was preceded by only a 3-day recovery period [84]. That insufficient recovery time between matches may cause performance deterioration and an increase in the risk of injury $[85,86]$.

Several authors have analyzed physical performance and injury rates during periods with 2-3 weekly games [68, 71, $74,85,87,88]$. Unexpectedly, they pointed out that the total distance covered and distances covered in high intensity running were not influenced by the short recovery period between matches, but instead were determined by situational variables. It must be noted that although a greater difference between halves has been found in the distance covered at high intensity during the second match compared to the first match when they played 2 consecutive matches separated by 3 days, this difference was not significant [87]. It has also been suggested that players are generally able to maintain skill-related performance throughout games and when competing in successive matches within a short time [27]. As a consequence, the analysis of actions that are metabolically taxing and greatly contribute to muscle damage (accelerations, decelerations and changes in direction) during fixture congestion is required for future research [62]. This could help to monitor the recovery status of soccer players.

Sleep provides a number of important psychological and physiological functions but sometimes is not enough to ensure complete recovery [89]. In addition, it has been suggested that reduced sleep quantity and quality and reduced perceived recovery are mainly evident following night matches in elite players [90]. Therefore, recovery strategies after exercise (based on the activity profile of each player) are an essential complement to prepare the next game or training session [52]. The effect of recovery interventions following soccer training is still debatable, due to a lack of studies performed in field situations [91]. For future research it would be interesting to analyze the importance of isolating each strategy and the potential interactions between the techniques [28].

\section{FATIGUE AND RECOVERY MARKERS IN SOCCER}

In team sports, several markers at rest or during activities with low neuromuscular and metabolic demands are often used [92]. In this context, a change in players' specific performance is the most relevant marker to differentiate fatigued from recovered athletes [17]. However, most of the field tests used in team sports are physically demanding and induce additional fatigue $[1,93]$. Performing these tests at frequent intervals could induce cumulative fatigue and thus alter the recovery kinetics from the initial exercise. Therefore, the battery of tests performed during recovery should be checked to make sure they do not lead to additional fatigue and affect the time course of recovery [1].

Unfortunately, there is a lack of consensus about the usefulness of tests used to monitor fatigue and recovery kinetics in team sport athletes [1, 92, 94]. Several indirect markers (performance, neuromuscular, subjective, and biochemical) are often used [1, 11]. Some markers are not accurate and/or reliable enough to measure muscle fatigue during exercise and its impact on skeletal muscle [95]. Given these difficulties, a variety of other markers should be frequently used in science and practice in order to track the stress and recovery processes $[10,17,96]$.

\section{a. Physical Performance Markers}

Performance is one of the best markers of fatigue and recovery, because it is one of the most important variables of success in competition [11]. Creating a simple and applicable battery of tests would allow for appropriate alteration of day-to-day training intensities and volumes, maximizing the potential for positive adaptations to training, avoiding overtraining and injury, and more importantly, improving match performance [97]. In any case, there is a lack of noninvasive methods for assessing an individual's level of recovery between sessions [97]. Several tests are usually used to evaluate physical performance of soccer players [98 - 100]. The order of the tests should also be taken into account: a battery of tests must start with short anaerobic tests (e.g. vertical jump) and end with strenuous tests (e.g. repeated sprints or aerobic performance) [1]. 


\section{i. Vertical Jump}

Muscular power is an important requirement for soccer performance [100] and it is usually measured by jump tests [101 - 103]. Fatigue impairs jump performance in soccer players [104], thus it could be useful to monitor fatigue. Immediately post-match, countermovement jump (CMJ) performance decreases [12, 59, 105], although several studies did not report significant decrements [106, 107] probably due to a 'warm-up' effect [108]. Decreases in vertical jump performance can remain 24 [2, 54], 48 [9, 109] and 72 hours post-exercise [59], so EIMD could play a role in this longterm power decrement. Anyway, 48 hours seems to be enough to return to baseline levels [2, 54]. Therefore, jumps can also be used to monitor the muscle status recovery indirectly. Vertical jump should be assessed during stretchshortening cycle (SSC) activities, because the complexity of SSC fatigue is well reflected by the recovery patterns of many neuromechanical parameters [110]. Squat jump (SJ) involves a single concentric action, whereas CMJ involves the SSC [111], thus CMJ testing is the most suitable for neuromuscular fatigue monitoring in soccer players and SJ to a lesser extent $[1,112]$.

\section{ii. Maximal Voluntary Strength}

The development of muscle fatigue is typically quantified as a decline in the maximal force or power capacity of muscle [113]. The decline in maximal voluntary strength after a soccer match appears to be a consequence of central fatigue, whereas muscle glycogen depletion, inflammation and muscle soreness per se are the most likely candidates explaining soccer match-induced peripheral fatigue $[4,5]$. Consequently, the highest level of central fatigue could be in players with the greatest maximal voluntary contraction decline after the match, whereas players with a large increase of muscle soreness experienced a greater degree of peripheral fatigue [4]. During maximal voluntary contraction evaluation, additional measurements (maximal voluntary activation or M-wave amplitude) could also be analyzed to determine the presence of central fatigue [4]. Several studies have used the maximal voluntary strength of the knee flexors/extensors as fatigue and recovery markers. Although several studies showed no decrement in the strength of these muscles [114 - 116], the strength of these muscles immediately post-match or specific soccer drills can significantly decrease compared to baseline values, but knee flexors strength decrement seems to be more pronounced than knee extensors strength $[4,5,12,52,59,107,117]$. Decrements of maximal voluntary strength at 72 hours postexercise could be related to EIMD [52, 59]. Moreover, the best method for quantifying EIMD is maximal voluntary contraction torque because is accurate and reliable [118].

\section{iii. Sprint and Repeated Sprint Ability}

Sprinting performance, an important determinant of physical performance in soccer [1], is decreased immediately post-match but it can be recovered between 5-96 hours post-match [2, 4, 12, 52 - 54, 58, 59]. That huge difference between studies depends on the high variability of physical performance such as high-intensity running distance during soccer matches, contextual factors, different performance levels, player's age, or training status. A relationship exists between central fatigue indicators and sprint performance decrements. A 48-hour reduction in voluntary activation was observed after an elite soccer match with a significant relationship $(r=20.63 ; p=0.01)$ between sprint performance decrement and maximal voluntary activation immediately after the match [4]. Moreover, the reduction in voluntary activation may be because of inhibition caused by muscle soreness [119] so changes in sprint performance during recovery period would have a rather peripheral impact than central fatigue [53]. As a result, it is a practical tool to monitor fatigue or recovery status.

Repeated Sprint Ability (RSA) can also be used after a match (to monitor match-related fatigue), or during recovery period (to identify players who are not able to cope with the intermittent demands of soccer). Indeed, significant correlations have been found between RSA mean time and the distance covered in very high-intensity running $(>19.8$ $\mathrm{km} / \mathrm{h})\left(\mathrm{r}=-0.60, \mathrm{R}^{2}=0.36 ; \mathrm{p}<0.01\right)$ and sprinting $(>25.2 \mathrm{~km} / \mathrm{h})\left(\mathrm{r}=-0.65, \mathrm{R}^{2}=0.42 ; \mathrm{p}<0.01\right)$ during official matches [120]. RSA tests are physically exhausting, which may explain the lack of studies with RSA tests during the recovery period compared to studies with single sprints. So, using RSA tests with few sprints is suitable during the recovery process [42, 106], but they should include changes of direction, a characteristic movement pattern of team sports [121]. However, the construct validity of classic tests of RSA in soccer is still debatable due to the various data available from timemotion analyses of sprints during games [24].

\section{iv. Aerobic Performance}

Soccer is an intermittent sport in which the aerobic energy system is highly taxed [30]. Players use their physical 
capacity during competitive games, so aerobic performance assessment can be useful to monitor post-match related fatigue. A game induced impairment in intermittent exercise performance can occur, and the type of fatigue that occurs in the late stage of a match has an impact on recovery capacity during sustained intense exercise bouts interspersed by short recovery periods [106]. Further research is necessary to assess aerobic fitness during recovery using protocols such as RSA tests [122 - 124] because aerobic performance measurements can induce fatigue and influence the recovery time course of anaerobic markers [1].

\section{b. Skill Performance}

Successful players perform better than others in skill-related actions, such as passing, shooting and dribbling [125, 126]. Technical skills could be deteriorated following high-intensity and localized muscle fatigue [127], but players seems to be able to preserve their technical abilities during and after a match $[4,27]$. Therefore, skill performance may not be a reliable tool to detect fatigued players after a soccer match.

\section{c. Subjetive Markers}

Coaches can use objective (performance, physiological, biochemical) and subjective measures for athletes' monitoring. Athletes can monitor their physiological stress during exercise as well as retrospectively provide information regarding their perceived effort post training or competition [95]. The perception of effort can be quantified by rating of perceived exertion (RPE) [128], a valid marker of exercise intensity [129] and a useful tool in the control of training load, exercise prescription and exercise monitoring [130, 131]. It can be used separately for respiratory (RPEres) and muscular (RPEmus) aspects [132, 133]. Consequently, this method is used extensively in soccer [53, 132 - 134]. Athletes are able to differentiate between perceived effort and other sensations, such as muscle pain, muscle tension, muscle discomfort or wellness (fatigue, vitality, sleep quality), so it can be a helpful non-invasive assessment of the fatigue-recovery cycle $[1,135,136]$. As a consequence, several questionnaires are also used in high-performance sport programs, such as Total Recovery Scale (TQR), Recovery-Stress Questionnaire for Athletes (REST-Q-Sport), Profile of Mood States (POMS), and Daily Analysis of Life Demands for Athletes (DALDA). Sometimes consistent associations between subjective and objective measurements have not been found [137] and athletes could manipulate data and/or over- or under-estimate training load [95]. Thus, subjective information may need to be corroborated with physiological data [138].

\section{d. Cognitive Markers}

A soccer match involves mental activities for both goalkeepers and outfield players [139], and mental fatigue has been shown to impact cognitive and physical performance [140, 141]. Neurocognitive mechanisms underlying the effects of mental fatigue are still poorly understood, although scientific evidence pointed out that mental fatigue is associated with lower cognitive performance and inadequate performance adjustments after errors [142]. Therefore, studies focusing on the assessment of cognitive markers during recovery are necessary to investigate the underlying component of mental fatigue in this context $[11,83]$. For instance, tasks of psychomotor speed (reaction time, motor time, response accuracy and speed, short-term memory task, etc) are relevant parameters to assess in the detection of fatigue or altered recovery-stress balance [140, 143].

\section{e. Biochemical Markers (Biomarkers)}

A biochemical, biological or muscle-status marker (biomarker) is a measurable product or substance used as an indicator of a biological state, to objectively determine the body's physiological or pathological processes [144]. Soccer causes an increase in metabolism with significant hematological changes [96, 145], thus information from biomarkers could be used to optimize training adaptation, training load, and match participation [83, 145, 146]. Biomarkers responses are influenced by several factors and reflect multiple interactions, so interpretation must be cautious [147]. To date, no single biomarker has been validated for daily routine [95]. As a result, several biomarkers must be considered together to understand the metabolic and physiological mechanisms underlying physical stress in soccer $[10,17,83$, 96]. Some of the most well-known biomarkers of fatigue are those originating from adenosine triphosphate (ATP) depletion or from immunology [10]. Considering that muscle fatigue may partly derive from EIMD [10], muscle damage biomarkers such as creatine kinase $(\mathrm{CK})$, myoglobin $(\mathrm{Mb})$ and lactate dehydrogenase $(\mathrm{LDH})$ and those related to inflammation, such as blood leukocyte count, interleukin-6 (IL-6) and C-reactive protein (CRP), could also be useful $[148,149]$. 
To which extent a shortage in ATP contributes to muscle fatigue is still currently under debate, but it has been shown that a decrease in available ATP at specific locations in association with the function of transport systems may contribute to the development of muscle fatigue [150]. Depletion of ATP, or increase in adenosine diphosphate (ADP), may contribute to muscle fatigue, thus biomarkers from the metabolism of ATP ([La], ammonia, and oxipurines) could be used to monitor acute fatigue [150]. [La] appears to be a meaningful biomarker of muscle fatigue if workload conditions are standardized [151]. Soccer is a sport consisting of high-intensity intermittent exercise, and [La] correlates with the magnitude of exercise performed immediately before blood sampling [152]. As a result, increases in [La] in soccer players must be used carefully as a biomarker of fatigue. Another marker to monitor metabolic activity, energy requirement and the onset of muscle fatigue is blood ammonia, which closely follows [La] response [151]. Ammonia increases after a soccer match $[153,154]$ and could have detrimental effects on fatigue-related performance, thus particular attention should be paid to their monitoring [153].

ATP can be synthesized by anaerobic or aerobic glycolysis, amongst others. In relation to muscle glycogen, urea concentration is a useful biomarker to evaluate athletes' level of fatigue and adaptation to training [155, 156]. Urea levels are highly variable among players due to dehydration [38], increased cyclic nucleotides and amino acid breakdown [157], or insufficient level of physical demands during soccer matches to induce significant changes in urea concentration [158]. At any case, more rest is needed if 24 hours post-exercise blood urea has not return to normal baseline concentration [159]. Limited information exists on the characteristics of elite-level players, but most studies have detected significant increases in post-match urea concentrations $[57,158,160]$. However, no significant changes in urea levels have been reported between periods of high and low competitive density during a season [161]. So more research is needed to understand the fatigue-recovery cycle and help coaches to improve individual training prescription.

Associated to immunological responses, monitoring hormonal parameters during professional soccer training could be useful to evaluate accumulated fatigue, overreaching and overtraining [162]. In this way, hormonal responses depend on many parameters, such as exercise duration and intensity, adaptation to exercise, homeostatic requirements, emotional and physical tension, ambient temperature, oxygen availability, and fatigue [157]. This may have an influence on the substantial fluctuation of testosterone (T) levels over a season, but an appropriate training program should not involve $\mathrm{T}$ declines that reflect the accumulation of fatigue throughout the season [162 - 165]. T decrement can also be detected after a match, so those players with smaller decreases in $\mathrm{T}$ concentration show lesser decrease in their immune function [166]. Nonetheless, conflicting results have been found in $\mathrm{T}$ responses after a soccer match [2, $56,167]$, probably due to factors such as location (home versus away), opposition standard (i.e. strong or weak team) [168], and match result [169]. Such as T, a large variability has also been found on cortisol (C) levels during the competitive seasons [162]. Training load, pressure to achieve results and adverse environmental conditions could be responsible for midseason increases found in some studies [165]. However, it is evident that post-match $\mathrm{C}$ levels are significantly greater compared to pre-match in semi-professional players [56], and they return to baseline levels between 24 [2] and 48 hours post-match [55]. When full competitive matches were played on consecutive days, C concentrations could be reduced, but additional research is needed to confirm this hypothesis [170]. To date, $\mathrm{C}$ may be used to monitor recovery processes and fatigue, even for short time periods [50,171]. Similarly, the ratio between the concentration of $\mathrm{T}$ and $\mathrm{C}(\mathrm{T} / \mathrm{C}$ ratio) is frequently used as indicative of the stress level imposed by the exercise: a decrease in $\mathrm{T} / \mathrm{C}$ ratio reflect catabolic stress. Even so, a decreased $\mathrm{T} / \mathrm{C}$ ratio does not automatically influence team performance decrements or team overtraining [96] because T/C ratio also shows significant changes during a competitive season, with significant increases at the end of pre-season and decreases at mid-season [162, 165]. It has been suggested that, in preseason, players are not fatigued and can respond adequately to the training demands (T/C ratio values reflect these adaptations), whereas mid-season values are not associated with overtraining syndrome but instead are linked to the volume and intensity of previous working loads (amount of competitions), the inability to adapt and/or hormonal dysfunction [162]. Although, no difference was seen in T/C ratio from pre-match to post-match in semi-professional soccer players [56], others authors pointed out that $\mathrm{T} / \mathrm{C}$ ratio can decrease by $64.2 \%$ after the match [166], and may stay low until 48 hours post-match [55]. The published results confirm that T/C ratio is highly variable [172]. Consequently, the variation in the relative free $\mathrm{T} / \mathrm{C}$ ratio to baseline is a better method for studying and preventing overtraining syndrome in comparison with traditional interpretative schemes (decrease $>30 \%$ ) [173].

Measurements of blood $\mathrm{CK}, \mathrm{LDH}$ and $\mathrm{Mb}$ are commonly mentioned in scientific literature to detect EIMD [174]. Post-match increases in plasma CK have been observed [158], and are smaller when pre-match levels are greater [175], but may go up to $84 \%(\mathrm{p}=0.17)$ when pre-match levels are in the normal ranges [56]. The majority of studies showed 
high concentrations of plasma $\mathrm{CK}$ at 24 [9, 53, 176], 48 [2, 50, 54, 55, 177], and 72 hours post-match [52]. Post-match increases in LDH have also been reported in elite and sub-elite female teams $(p<0.01)$ [167], which can be greater 48 hours post-match [2] and maintained 72 hours post-competition [2, 52]. Moreover, Mb increases from pre-match to post-match could also remain until 72 hours post-match $[2,52,55]$. Therefore, it seems that muscle damage biomarkers response follows the same pattern. Among these substances, CK is considered the best indicator of a breakdown in muscle cell structure [174]. However, the substantial individual variability in CK responses to the same exercise bouts could reduce the usefulness as a biomarker of players' recovery status [178].

Inflammatory processes are induced during exercise as a result of muscle metabolism and EIMD. The most frequently reported biomarkers of the inflammatory response include blood leukocyte count, IL-6 and CRP [148]. IL-6 increases immediately after a soccer match, but drops rapidly to pre-match levels and returns to baseline 24 hours postmatch $[2,60,176]$, whereas neutrophil counts can remain significantly elevated 48 hours post-match [50] and CRP peak may occur between $24-48$ hours post-exercise [55, 58]. As a result, it can be confirmed that a single soccer game induces marked but transient inflammatory responses and clearly indicates the need of enough recovery for elite soccer players after a match [2].

In any case, these measurements are not convenient for repeated field measures in players, and improvement in these markers seems much less useful if performance is not improved [11]. Biomarkers measurements should not replace performance testing, and they might be used together to provide additional information about the underlying physiology [179].

\begin{tabular}{|c|c|c|c|}
\hline Marker & Fatigue & EIMD & $\begin{array}{l}\text { Training } \\
\text { recovery }\end{array}$ \\
\hline $\begin{array}{l}\text { Vertical } \\
\text { Jump }\end{array}$ & & & \\
\hline $\begin{array}{l}\text { Maximal } \\
\text { voluntary } \\
\text { strength }\end{array}$ & & & \\
\hline Sprint & & & $v$ \\
\hline RSA & & & \\
\hline $\begin{array}{c}\text { Aerobic } \\
\text { tests }\end{array}$ & & & \\
\hline $\begin{array}{c}\text { Skill } \\
\text { performance }\end{array}$ & & & \\
\hline $\begin{array}{c}\text { Subjective } \\
\text { markers }\end{array}$ & & & \\
\hline $\begin{array}{l}\text { Cognitive } \\
\text { markers }\end{array}$ & & & \\
\hline Lactate & & & \\
\hline Ammonia & & X & X \\
\hline Urea & & X & $\checkmark$ \\
\hline Testosterone & & & $\checkmark$ \\
\hline Cortisol & & & $\checkmark$ \\
\hline $\mathrm{T} / \mathrm{C}$ ratio & & & $\checkmark$ \\
\hline $\mathrm{CK}$ & & $\checkmark$ & $\checkmark$ \\
\hline $\mathrm{LDH}$ & & $\checkmark$ & $\checkmark$ \\
\hline Myoglobin & & $\checkmark$ & $\checkmark$ \\
\hline IL-6 & & $\checkmark$ & $\checkmark$ \\
\hline CRP & X & $\checkmark$ & $\checkmark$ \\
\hline
\end{tabular}

Fig. (1). Summary of markers and their usefulness. $\checkmark$ : useful; $\mathrm{X}$ : not useful; ? : further research is needed to confirm their usefulness.

\section{CONCLUSION}

Soccer players experience high physiological stress during an exhausting soccer match or training session. These 
physiological changes result in fatigue which can decrease performance. Moreover, physical performance decrements are also influenced by the specific demands of each game. This may explain the high variability in the metabolic, physiological and psychological responses of players during soccer matches or trainings. The magnitude of EIMD can also be different according to the requirements of each game and players' characteristics and it could explain interindividual variability in recovery processes in players of the same team. From a practical point of view, the variability of the responses amongst players leads us to recommend an individual analysis of the results. To assess the readiness of soccer players to put up with the high demands of soccer, researchers have used several markers, but there is a lack of consensus on the usefulness of some of them. Therefore coaches must use markers with high accuracy and combining, at least, one performance, one cognitive or subjective, and one biochemical marker. The analysis of this review may therefore provide important information to coaches, help them to design training schedules and improve individual training prescription, to monitor the recovery status of soccer players, and to adjust players' recovery strategies.

\section{LIST OF ABBREVIATIONS}

\begin{tabular}{|c|c|c|}
\hline ATP & $=$ & Adenosine triphosphate \\
\hline ADP & $=$ & Adenosine diphosphate \\
\hline $\mathbf{C}$ & $=$ & Cortisol \\
\hline CK & $=$ & Creatine kinase \\
\hline CMJ & $=$ & Countermovement jump \\
\hline CRP & $=$ & C-reactive protein \\
\hline DALDA & $=$ & Daily Analysis of Life Demands for Athletes \\
\hline DJ & $=$ & Drop jump \\
\hline EIMD & $=$ & Exercise-induced muscle damage \\
\hline IL-6 & $=$ & Interleukin 6 \\
\hline LDH & $=$ & Lactate dehydrogenase \\
\hline Mb & $=$ & Myoglobin \\
\hline POMS & $=$ & Profile of Mood States \\
\hline REST-Q-Sport & $=$ & Recovery-Stress Questionnaire for Athletes \\
\hline RPE & $=$ & perceived exertion scale \\
\hline RPEmus & $=$ & Musculature perceived exertion scale \\
\hline RPEres & $=$ & Respiratory perceived exertion scale \\
\hline RSA & $=$ & Repeated sprint ability \\
\hline SSC & $=$ & Stretch-shortening cycle \\
\hline SJ & $=$ & Squat jump \\
\hline $\mathbf{T}$ & $=$ & Testosterone \\
\hline TQR & $=$ & Total Recovery Scale \\
\hline $\mathbf{T} / \mathbf{C}$ & $=$ & Testosterone/cortisol ratio \\
\hline [La] & $=$ & Blood lactate concentration \\
\hline
\end{tabular}

\section{CONFLICT OF INTEREST}

The authors have no support or funding to report, and declare they have no conflict of interest related to the content of this comprehensive review.

\section{ACKNOWLEDGEMENTS}

Declared none.

\section{REFERENCES}

[1] Nédélec M, McCall A, Carling C, Legall F, Berthoin S, Dupont G. Recovery in soccer: part I - post-match fatigue and time course of recovery. Sports Med 2012; 42(12): 997-1015.

[PMID: 23046224]

[2] Ispirlidis I, Fatouros IG, Jamurtas AZ, et al. Time-course of changes in inflammatory and performance responses following a soccer game. Clin J Sport Med 2008; 18(5): 423-31. 
[http://dx.doi.org/10.1097/JSM.0b013e3181818e0b] [PMID: 18806550]

[3] Meeusen R, Watson P, Hasegawa H, Roelands B, Piacentini MF. Central fatigue: the serotonin hypothesis and beyond. Sports Med 2006; 36(10): 881-909.

[http://dx.doi.org/10.2165/00007256-200636100-00006] [PMID: 17004850]

[4] Rampinini E, Bosio A, Ferraresi I, Petruolo A, Morelli A, Sassi A. Match-related fatigue in soccer players. Med Sci Sports Exerc 2011; 43(11): 2161-70. [http://dx.doi.org/10.1249/MSS.0b013e31821e9c5c] [PMID: 21502891]

[5] Robineau J, Jouaux T, Lacroix M, Babault N. Neuromuscular fatigue induced by a 90-minute soccer game modeling. J Strength Cond Res 2012; 26(2): 555-62. [http://dx.doi.org/10.1519/JSC.0b013e318220dda0] [PMID: 22240545]

[6] Bradley PS, Noakes TD. Match running performance fluctuations in elite soccer: indicative of fatigue, pacing or situational influences? J Sports Sci 2013; 31(15): 1627-38.

[http://dx.doi.org/10.1080/02640414.2013.796062] [PMID: 23808376]

[7] Bradley PS, Sheldon W, Wooster B, Olsen P, Boanas P, Krustrup P. High-intensity running in English FA Premier League soccer matches. J Sports Sci 2009; 27(2): 159-68. [http://dx.doi.org/10.1080/02640410802512775] [PMID: 19153866]

[8] Rampinini E, Coutts AJ, Castagna C, Sassi R, Impellizzeri FM. Variation in top level soccer match performance. Int J Sports Med 2007; 28(12): 1018-24. [http://dx.doi.org/10.1055/s-2007-965158] [PMID: 17497575]

[9] de Hoyo M, Cohen DD, Sañudo B, et al. Influence of football match time-motion parameters on recovery time course of muscle damage and jump ability. J Sports Sci 2016; 34(14): 1363-70.

[http://dx.doi.org/10.1080/02640414.2016.1150603] [PMID: 26930226]

[10] Finsterer J, Drory VE. Wet, volatile, and dry biomarkers of exercise-induced muscle fatigue. BMC Musculoskelet Disord 2016; 17: 40. [http://dx.doi.org/10.1186/s12891-016-0869-2] [PMID: 26790722]

[11] Bishop PA, Jones E, Woods AK. Recovery from training: A brief review. J Strength Cond Res 2008; $22(3)$ : $1015-24$. [http://dx.doi.org/10.1519/JSC.0b013e31816eb518] [PMID: 18438210]

[12] Andersson H, Raastad T, Nilsson J, Paulsen G, Garthe I, Kadi F. Neuromuscular fatigue and recovery in elite female soccer: effects of active recovery. Med Sci Sports Exerc 2008; 40(2): 372-80.

[http://dx.doi.org/10.1249/mss.0b013e31815b8497] [PMID: 18202563]

[13] Carling C, Le Gall F, Dupont G. Are physical performance and injury risk in a professional soccer team in match-play affected over a prolonged period of fixture congestion? Int J Sports Med 2012; 33(1): 36-42. [http://dx.doi.org/10.1055/s-0031-1283190] [PMID: 22012641]

[14] Terrados N, Calleja-González J, Schelling X. Bases fisiológicas comunes para deportes de equipo. Rev Andaluza Med Deporte 2011; (2): 84-8.

[15] Terrados N, Calleja-González J, Jukic I, Ostojic SM. Physiological and medical strategies in post-competition recovery-practical implications based on scientific evidence. Serb J Sports Sci 2009; 3(1-4): 29-37.

[16] Calleja-González J, Terrados N, Mielgo-Ayuso J, et al. Evidence-based post-exercise recovery strategies in basketball. Phys Sportsmed 2016; 44(1): 74-8 [http://dx.doi.org/10.1080/00913847.2016.1102033] [PMID: 26512912]

[17] Wiewelhove T, Raeder C, Meyer T, Kellmann M, Pfeiffer M, Ferrauti A. Markers for Routine Assessment of Fatigue and Recovery in Male and Female Team Sport Athletes during High-Intensity Interval Training. PLoS One 2015; 10(10): e0139801. [http://dx.doi.org/10.1371/journal.pone.0139801] [PMID: 26444557]

[18] Mohr M, Krustrup P, Bangsbo J. Fatigue in soccer: a brief review. J Sports Sci 2005; 23(6): 593-9. [http://dx.doi.org/10.1080/02640410400021286] [PMID: 16195008]

[19] Mohr M, Krustrup P, Bangsbo J. Match performance of high-standard soccer players with special reference to development of fatigue. J Sports Sci 2003; 21(7): 519-28.

[http://dx.doi.org/10.1080/0264041031000071182] [PMID: 12848386]

[20] Bradley PS, Di Mascio M, Peart D, Olsen P, Sheldon B. High-intensity activity profiles of elite soccer players at different performance levels. J Strength Cond Res 2010; 24(9): 2343-51 [http://dx.doi.org/10.1519/JSC.0b013e3181aeb1b3] [PMID: 19918194]

[21] Sparks M, Coetzee B, Gabbett TJ. Variations in high-intensity running and fatigue during semi-professional soccer matches. Int J Perf Anal Sport 2016; 16(1): 122-32.

[22] Lago-Peñas C. The role of situational variables in analysing physical performance in soccer. J Hum Kinet 2012; 35: 89-95. [http://dx.doi.org/10.2478/v10078-012-0082-9] [PMID: 23487326]

[23] Carling C, Bradley P, McCall A, Dupont G. Match-to-match variability in high-speed running activity in a professional soccer team. J Sports Sci 2016; 34(24): 2215-23. [http://dx.doi.org/10.1080/02640414.2016.1176228] [PMID: 27144879] 
[24] Schimpchen J, Skorski S, Nopp S, Meyer T. Are classical tests of repeated-sprint ability in football externally valid? A new approach to determine in-game sprinting behaviour in elite football players. J Sports Sci 2016; 34(6): 519-26. [http://dx.doi.org/10.1080/02640414.2015.1112023] [PMID: 26580089]

[25] Krustrup P, Ørtenblad N, Nielsen J, et al. Maximal voluntary contraction force, SR function and glycogen resynthesis during the first $72 \mathrm{~h}$ after a high-level competitive soccer game. Eur J Appl Physiol 2011; 111(12): 2987-95. [http://dx.doi.org/10.1007/s00421-011-1919-y] [PMID: 21448723]

[26] Marshall PW, Lovell R, Jeppesen GK, Andersen K, Siegler JC. Hamstring muscle fatigue and central motor output during a simulated soccer match. PLoS One 2014; 9(7): e102753.

[http://dx.doi.org/10.1371/journal.pone.0102753] [PMID: 25047547]

[27] Carling C, Dupont G. Are declines in physical performance associated with a reduction in skill-related performance during professional soccer match-play? J Sports Sci 2011; 29(1): 63-71. [http://dx.doi.org/10.1080/02640414.2010.521945] [PMID: 21077004]

[28] Nédélec M, McCall A, Carling C, Legall F, Berthoin S, Dupont G. Recovery in soccer: part ii-recovery strategies. Sports Med 2013; 43(1): $9-22$. [http://dx.doi.org/10.1007/s40279-012-0002-0] [PMID: 23315753]

[29] Saltin B. Metabolic fundamentals in exercise. Med Sci Sports 1973; 5(3): 137-46. [PMID: 4270581]

[30] Bangsbo J, Mohr M, Krustrup P. Physical and metabolic demands of training and match-play in the elite football player. J Sports Sci 2006; 24(7): 665-74

[http://dx.doi.org/10.1080/02640410500482529] [PMID: 16766496]

[31] Krustrup P, Mohr M, Steensberg A, Bencke J, Kjaer M, Bangsbo J. Muscle and blood metabolites during a soccer game: implications for sprint performance. Med Sci Sports Exerc 2006; 38(6): 1165-74. [http://dx.doi.org/10.1249/01.mss.0000222845.89262.cd] [PMID: 16775559]

[32] Shephard RJ. Biology and medicine of soccer: an update. J Sports Sci 1999; 17(10): 757-86. [http://dx.doi.org/10.1080/026404199365498] [PMID: 10573331]

[33] Bangsbo J, Nørregaard L, Thorsøe F. The effect of carbohydrate diet on intermittent exercise performance. Int J Sports Med 1992; 13(2): $152-7$. [http://dx.doi.org/10.1055/s-2007-1021247] [PMID: 1555905]

[34] Rienzi E, Drust B, Reilly T, Carter JE, Martin A. Investigation of anthropometric and work-rate profiles of elite South American international soccer players. J Sports Med Phys Fitness 2000; 40(2): 162-9. [PMID: 11034438]

[35] Bangsbo J. The physiology of soccer-with special reference to intense intermittent exercise. Acta Physiol Scand 1999; 619: 1-155.

[36] Krustrup P, Mohr M, Steensberg A, Bencke J, Kjaer M, Bangsbo J. Muscle metabolites during a football match in relation to a decreased sprinting ability. Proceedings of the 5th World Congress of Soccer and Science. Lisbon, Portugal. 2003.

[37] Reilly T. Energetics of high-intensity exercise (soccer) with particular reference to fatigue. J Sports Sci 1997; 15(3): $257-63$. [http://dx.doi.org/10.1080/026404197367263] [PMID: 9232551]

[38] Mohr M, Mujika I, Santisteban J, et al. Examination of fatigue development in elite soccer in a hot environment: a multi-experimental approach. Scand J Med Sci Sports 2010; 20(s3)(Suppl. 3): 125-32. [http://dx.doi.org/10.1111/j.1600-0838.2010.01217.x] [PMID: 21029199]

[39] Reilly T, Lewis W, Brown ID, Goldsmith R. Effects of carbohydrate feeding on mental funtions during sustained physical work. In: Brown ID, Goldsmith R, Coombes K, Sinclair MA, Eds. Ergonomics International. London: Taylor and Frances 1985; pp. $700-2$.

[40] Cable NT, Bullock S. Thermoregulatory response during and in recovery from aerobic and anaerobic exercise 1201. Med Sci Sports Exerc 1996; 28(5): 202. [http://dx.doi.org/10.1097/00005768-199605001-01199]

[41] Nybo L, Nielsen B. Hyperthermia and central fatigue during prolonged exercise in humans. J Appl Physiol 2001; 91(3): 1055-60. [PMID: 11509498]

[42] Mohr M, Krustrup P, Nybo L, Nielsen JJ, Bangsbo J. Muscle temperature and sprint performance during soccer matchesbeneficial effect of re-warm-up at half-time. Scand J Med Sci Sports 2004; 14(3): 156-62. [http://dx.doi.org/10.1111/j.1600-0838.2004.00349.x] [PMID: 15144355]

[43] Mohr M, Rasmussen P, Drust B, Nielsen B, Nybo L. Environmental heat stress, hyperammonemia and nucleotide metabolism during intermittent exercise. Eur J Appl Physiol 2006; 97(1): 89-95. [http://dx.doi.org/10.1007/s00421-006-0152-6] [PMID: 16485104]

[44] Nybo L. CNS fatigue provoked by prolonged exercise in the heat. Front Biosci (Elite Ed) 2010; 2(2): 779-92. [http://dx.doi.org/10.2741/e138] [PMID: 20036922]

[45] Badin OO, Smith MR, Conte D, Coutts AJ. Mental Fatigue Impairs Technical Performance in Small-Sided Soccer Games. Int J Sports Physiol 2016. Perform (ahead of print). 
[46] Smith MR, Zeuwts L, Lenoir M, Hens N, De Jong LM, Coutts AJ. Mental fatigue impairs soccer-specific decision-making skill. J Sports Sci 2016; 34(14): 1297-304. [http://dx.doi.org/10.1080/02640414.2016.1156241] [PMID: 26949830]

[47] Smith MR, Coutts AJ, Merlini M, Deprez D, Lenoir M, Marcora SM. Mental fatigue impairs soccer-specific physical and technical performance. Med Sci Sports Exerc 2016; 48(2): 267-76 [http://dx.doi.org/10.1249/MSS.0000000000000762] [PMID: 26312616]

[48] Silva JR, Rebelo A, Marques F, et al. Biochemical impact of soccer: an analysis of hormonal, muscle damage, and redox markers during the season. Appl Physiol Nutr Metab 2014; 39(4): 432-8. [http://dx.doi.org/10.1139/apnm-2013-0180] [PMID: 24669984]

[49] Fridén J, Sjöström M, Ekblom B. Myofibrillar damage following intense eccentric exercise in man. Int J Sports Med 1983; 4(3): 170-6. [http://dx.doi.org/10.1055/s-2008-1026030] [PMID: 6629599]

[50] Romagnoli M, Sanchis-Gomar F, Alis R, Risso-Ballester J, Bosio A, Graziani RL, et al. Changes in muscle damage, inflammation, and fatigue-related parameters in young elite soccer players after a match. J Sports Med Phys Fitness 2015. ahead of print.

[51] Russell M, Northeast J, Atkinson G, et al. The between-match variability of peak power output and Creatine Kinase responses to soccer match-play. J Strength Cond Res 2015; 29(8): 2079-85.

[http://dx.doi.org/10.1519/JSC.0000000000000852] [PMID: 25627642]

[52] Ascensão A, Rebelo A, Oliveira E, Marques F, Pereira L, Magalhães J. Biochemical impact of a soccer match - analysis of oxidative stress and muscle damage markers throughout recovery. Clin Biochem 2008; 41(10-11): 841-51. [http://dx.doi.org/10.1016/j.clinbiochem.2008.04.008] [PMID: 18457670]

[53] Djaoui L, Diaz-Cidoncha Garcia J, Hautier C, Dellal A. Kinetic Post-match Fatigue in Professional and Youth Soccer Players During the Competitive Period. Asian J Sports Med 2016; 7(1): e28267. [PMID: 27217927]

[54] Fatouros IG, Chatzinikolaou A, Douroudos II, et al. Time-course of changes in oxidative stress and antioxidant status responses following a soccer game. J Strength Cond Res 2010; 24(12): 3278-86. [http://dx.doi.org/10.1519/JSC.0b013e3181b60444] [PMID: 19996787]

[55] Silva JR, Ascensão A, Marques F, Seabra A, Rebelo A, Magalhães J. Neuromuscular function, hormonal and redox status and muscle damage of professional soccer players after a high-level competitive match. Eur J Appl Physiol 2013; 113(9): $2193-201$. [http://dx.doi.org/10.1007/s00421-013-2633-8] [PMID: 23661147]

[56] Thorpe R, Sunderland C. Muscle damage, endocrine, and immune marker response to a soccer match. J Strength Cond Res 2012; 26(10): 2783-90.

[http://dx.doi.org/10.1519/JSC.0b013e318241e174] [PMID: 22124357]

[57] Andersson H, Bøhn SK, Raastad T, Paulsen G, Blomhoff R, Kadi F. Differences in the inflammatory plasma cytokine response following two elite female soccer games separated by a 72-h recovery. Scand J Med Sci Sports 2010; 20(5): 740-7. [http://dx.doi.org/10.1111/j.1600-0838.2009.00989.x] [PMID: 19765242]

[58] Ingram J, Dawson B, Goodman C, Wallman K, Beilby J. Effect of water immersion methods on post-exercise recovery from simulated team sport exercise. J Sci Med Sport 2009; 12(3): 417-21. [http://dx.doi.org/10.1016/j.jsams.2007.12.011] [PMID: 18547863]

[59] Magalhães J, Rebelo A, Oliveira E, Silva JR, Marques F, Ascensão A. Impact of Loughborough Intermittent Shuttle Test versus soccer match on physiological, biochemical and neuromuscular parameters. Eur J Appl Physiol 2010; 108(1): 39-48.

[http://dx.doi.org/10.1007/s00421-009-1161-z] [PMID: 19756713]

[60] Andersson H, Karlsen A, Blomhoff R, Raastad T, Kadi F. Active recovery training does not affect the antioxidant response to soccer games in elite female players. Br J Nutr 2010; 104(10): 1492-9. [http://dx.doi.org/10.1017/S0007114510002394] [PMID: 20609267]

[61] Clarkson PM, Nosaka K, Braun B. Muscle function after exercise-induced muscle damage and rapid adaptation. Med Sci Sports Exerc 1992; 24(5): 512-20. [http://dx.doi.org/10.1249/00005768-199205000-00004] [PMID: 1569847]

[62] Carling C, Gregson W, McCall A, Moreira A, Wong P, Bradley PS. Match running performance during fixture congestion in elite soccer: research issues and future directions. Sports Med 2015; 45(5): 605-13. [http://dx.doi.org/10.1007/s40279-015-0313-z] [PMID: 25694027]

[63] Nieman DC, Bishop NC. Nutritional strategies to counter stress to the immune system in athletes, with special reference to football. J Sports Sci $2006 ; 24(7): 763-72$. [http://dx.doi.org/10.1080/02640410500482982] [PMID: 16766504]

[64] Reilly T, Ekblom B. The use of recovery methods post-exercise. J Sports Sci 2005; 23(6): 619-27. [http://dx.doi.org/10.1080/02640410400021302] [PMID: 16195010]

[65] Shephard RJ. Physical activity, training and the immune response. Carmel, IN: Cooper 1997.

[66] Drust B, Atkinson G, Reilly T. Future perspectives in the evaluation of the physiological demands of soccer. Sports Med 2007; 37(9): 783-805. 
[http://dx.doi.org/10.2165/00007256-200737090-00003] [PMID: 17722949]

[67] Wallace JL, Norton KI. Evolution of World Cup soccer final games 19662010: game structure, speed and play patterns. J Sci Med Sport 2014; 17(2): 223-8.

[http://dx.doi.org/10.1016/j.jsams.2013.03.016] [PMID: 23643671]

[68] Lago C. The influence of match location, quality of opposition, and match status on possession strategies in professional association football. J Sports Sci 2009; 27(13): 1463-9. [http://dx.doi.org/10.1080/02640410903131681] [PMID: 19757296]

[69] Zubillaga A, Gorospe G, Mendo AH, Villaseñor AB. Match analysis of 2005-06 champions league final with Amisco system. J Sports Sci Med 2007; 6(10).

[70] Bloomfield JR, Polman RC, O’Donoghue PG. Effects of score-line on team strategies in FA Premier League Soccer. J Sports Sci 2005; 23(2): 192-3.

[71] Lago C, Casais L, Dominguez E, Sampaio J. The effects of situational variables on distance covered at various speeds in elite soccer. Eur J Sport Sci 2010; 10(2): 103-9.

[http://dx.doi.org/10.1080/17461390903273994]

[72] Bradley PS, Carling C, Archer D, et al. The effect of playing formation on high-intensity running and technical profiles in English FA Premier League soccer matches. J Sports Sci 2011; 29(8): 821-30. [http://dx.doi.org/10.1080/02640414.2011.561868] [PMID: 21512949]

[73] Schuth G, Carr G, Barnes C, Carling C, Bradley PS. Positional interchanges influence the physical and technical match performance variables of elite soccer players. J Sports Sci 2016; 34(6): 501-8.

[http://dx.doi.org/10.1080/02640414.2015.1127402] [PMID: 26700131]

[74] Lago-Peñas C, Rey E, Lago-Ballesteros J, Casáis L, Domínguez E. The influence of a congested calendar on physical performance in elite soccer. J Strength Cond Res 2011; 25(8): 2111-7. [http://dx.doi.org/10.1519/JSC.0b013e3181eccdd2] [PMID: 21572352]

[75] Castellano J, Blanco-Villaseñor A, Alvarez D. Contextual variables and time-motion analysis in soccer. Int J Sports Med 2011; 32(6): 415-21. [http://dx.doi.org/10.1055/s-0031-1271771] [PMID: 21590641]

[76] O'Donoghue P, Tenga A. The effect of score-line on work rate in elite soccer. J Sports Sci 2001; 19(1): 25-6.

[77] Pollard R. Home advantage in football: A current review of an unsolved puzzle. Open Sports Sci J 2008; 1(1): 12-4. [http://dx.doi.org/10.2174/1875399X00801010012]

[78] Carling C, Williams AM, Reilly T. Handbook of soccer match analysis: A systematic approach to improving performance. J Sports Sci Med 2005; 5(1): 171.

[79] Paul DJ, Bradley PS, Nassis GP. Factors affecting match running performance of elite soccer players: shedding some light on the complexity. Int J Sports Physiol Perform 2015; 10(4): 516-9. [http://dx.doi.org/10.1123/ijspp.2015-0029] [PMID: 25928752]

[80] Fell J, Williams D. The effect of aging on skeletal-muscle recovery from exercise: possible implications for aging athletes. J Aging Phys Act 2008; 16(1): 97-115.

[http://dx.doi.org/10.1123/japa.16.1.97] [PMID: 18268815]

[81] Magal M, Dumke CL, Urbiztondo ZG, et al. Relationship between serum creatine kinase activity following exercise-induced muscle damage and muscle fibre composition. J Sports Sci 2010; 28(3): 257-66. [http://dx.doi.org/10.1080/02640410903440892] [PMID: 20077274]

[82] Rainer P. The physiological effect of playing three simulated matches in a week: implications for overtraining/overplaying. In: Reilly T, Bangsbo J, Hughes M, Eds. Science and Football III London: E y FN Spon. 1997; pp. 350-4.

[83] Nedelec M, McCall A, Carling C, Legall F, Berthoin S, Dupont G. The influence of soccer playing actions on the recovery kinetics after a soccer match. J Strength Cond Res 2014; 28(6): 1517-23. [http://dx.doi.org/10.1519/JSC.0000000000000293] [PMID: 24172722]

[84] Mohr M, Draganidis D, Chatzinikolaou A, Barbero-Álvarez JC, Castagna C, Douroudos I, et al. Muscle damage, inflammatory, immune and performance responses to three football games in 1 week in competitive male players. Eur J Appl Physiol 2015; 1-15. [PMID: 26377004]

[85] Dupont G, Nedelec M, McCall A, McCormack D, Berthoin S, Wisløff U. Effect of 2 soccer matches in a week on physical performance and injury rate. Am J Sports Med 2010; 38(9): 1752-8.

[http://dx.doi.org/10.1177/0363546510361236] [PMID: 20400751]

[86] Ekstrand J, Waldén M, Hägglund M. A congested football calendar and the wellbeing of players: correlation between match exposure of European footballers before the World Cup 2002 and their injuries and performances during that World Cup. Br J Sports Med 2004; 38(4): 493-7.

[http://dx.doi.org/10.1136/bjsm.2003.009134] [PMID: 15273193]

[87] Rey E, Lago C, Lago-Ballesteros J, Casais L, Dellal A. The effect of cumulative fatigue on activity profiles of professional soccer players during a congested fixture period. Biol Sport 2010; 27(3): 181-5. [http://dx.doi.org/10.5604/20831862.919337] 
[88] Odetoyinbo K, Wooster B, Lane A. The effect of a succession of matches on the activity profiles of professional soccer players. In: Reilly T, Korkusuz F, Eds. Science and football VI. London: Routledge 2008; pp. 182-5.

[89] Nédélec M, Halson S, Abaidia A-E, Ahmaidi S, Dupont G. Stress, sleep and recovery in elite soccer: a critical review of the literature. Sports Med 2015; 45(10): 1387-400.

[http://dx.doi.org/10.1007/s40279-015-0358-z] [PMID: 26206724]

[90] Fullagar HH, Skorski S, Duffield R, Julian R, Bartlett J, Meyer T. Impaired sleep and recovery after night matches in elite football players. J Sports Sci 2016; 34(14): 1333-9. [http://dx.doi.org/10.1080/02640414.2015.1135249] [PMID: 26750446]

[91] Tessitore A, Meeusen R, Cortis C, Capranica L. Effects of different recovery interventions on anaerobic performances following preseason soccer training. J Strength Cond Res 2007; 21(3): 745-50. [http://dx.doi.org/10.1519/R-20386.1] [PMID: 17685701]

[92] Urhausen A, Kindermann W. Diagnosis of overtraining: what tools do we have? Sports Med 2002; 32(2): 95-102. [http://dx.doi.org/10.2165/00007256-200232020-00002] [PMID: 11817995]

[93] Bangsbo J, Lindquist F. Comparison of various exercise tests with endurance performance during soccer in professional players. Int J Sports Med 1992; 13(2): 125-32.

[http://dx.doi.org/10.1055/s-2007-1021243] [PMID: 1555901]

[94] Meeusen R, Duclos M, Foster C, et al. Prevention, diagnosis, and treatment of the overtraining syndrome: joint consensus statement of the European College of Sport Science and the American College of Sports Medicine. Med Sci Sports Exerc 2013; 45(1): 186-205. [http://dx.doi.org/10.1249/MSS.0b013e318279a10a] [PMID: 23247672]

[95] Halson SL. Monitoring training load to understand fatigue in athletes. Sports Med 2014; 44(Suppl 2): S139-47. [http://dx.doi.org/10.1007/s40279-014-0253-z] [PMID: 25200666]

[96] Filaire E, Bernain X, Sagnol M, Lac G. Preliminary results on mood state, salivary testosterone:cortisol ratio and team performance in a professional soccer team. Eur J Appl Physiol 2001; 86(2): 179-84. [http://dx.doi.org/10.1007/s004210100512] [PMID: 11822478]

[97] Sjökvist J, Laurent MC, Richardson M, Curtner-Smith M, Holmberg H-C, Bishop PA. Recovery from high-intensity training sessions in female soccer players. J Strength Cond Res 2011; 25(6): 1726-35. [http://dx.doi.org/10.1519/JSC.0b013e3181e06de8] [PMID: 21386721]

[98] Chamari K, Hachana Y, Ahmed YB, et al. Field and laboratory testing in young elite soccer players. Br J Sports Med 2004; 38(2): 191-6. [http://dx.doi.org/10.1136/bjsm.2002.004374] [PMID: 15039258]

[99] Stølen T, Chamari K, Castagna C, Wisløff U. Physiology of soccer: an update. Sports Med 2005; 35(6): $501-36$. [http://dx.doi.org/10.2165/00007256-200535060-00004] [PMID: 15974635]

[100] Svensson M, Drust B. Testing soccer players. J Sports Sci 2005; 23(6): 601-18. [http://dx.doi.org/10.1080/02640410400021294] [PMID: 16195009]

[101] Kotzamanidis C, Chatzopoulos D, Michailidis C, Papaiakovou G, Patikas D. The effect of a combined high-intensity strength and speed training program on the running and jumping ability of soccer players. J Strength Cond Res 2005; 19(2): 369-75. [PMID: 15903377]

[102] Helgerud J, Engen LC, Wisloff U, Hoff J. Aerobic endurance training improves soccer performance. Med Sci Sports Exerc 2001; 33(11): 1925-31. [http://dx.doi.org/10.1097/00005768-200111000-00019] [PMID: 11689745]

[103] Siegler J, Gaskill S, Ruby B. Changes evaluated in soccer-specific power endurance either with or without a 10-week, in-season, intermittent, high-intensity training protocol. J Strength Cond Res 2003; 17(2): 379-87. [PMID: 12741882]

[104] Oliver J, Armstrong N, Williams C. Changes in jump performance and muscle activity following soccer-specific exercise. J Sports Sci 2008; 26(2): 141-8.

[http://dx.doi.org/10.1080/02640410701352018] [PMID: 17852695]

[105] Oliver JL, Armstrong N, Williams CA. Reliability and validity of a soccer-specific test of prolonged repeated-sprint ability. Int J Sports Physiol Perform 2007 2015; 2(2): 137.

[106] Krustrup P, Zebis M, Jensen JM, Mohr M. Game-induced fatigue patterns in elite female soccer. J Strength Cond Res 2010; $24(2)$ : 437-41. [http://dx.doi.org/10.1519/JSC.0b013e3181c09b79] [PMID: 20072057]

[107] Thorlund JB, Aagaard P, Madsen K. Rapid muscle force capacity changes after soccer match play. Int J Sports Med 2009; $30(4)$ : 273-8. [http://dx.doi.org/10.1055/s-0028-1104587] [PMID: 19199196]

[108] Shellock FG, Prentice WE. Warming-up and stretching for improved physical performance and prevention of sports-related injuries. Sports Med 1985; 2(4): 267-78.

[http://dx.doi.org/10.2165/00007256-198502040-00004] [PMID: 3849057]

[109] Bailey DM, Erith SJ, Griffin PJ, et al. Influence of cold-water immersion on indices of muscle damage following prolonged intermittent shuttle running. J Sports Sci 2007; 25(11): 1163-70. 
[http://dx.doi.org/10.1080/02640410600982659] [PMID: 17654228]

[110] Nicol C, Avela J, Komi PV. The stretch-shortening cycle : a model to study naturally occurring neuromuscular fatigue. Sports Med 2006; 36(11): 977-99.

[http://dx.doi.org/10.2165/00007256-200636110-00004] [PMID: 17052133]

[111] Bobbert MF, Gerritsen KG, Litjens MC, Van Soest AJ. Why is countermovement jump height greater than squat jump height? Med Sci Sports Exerc 1996; 28(11): 1402-12.

[http://dx.doi.org/10.1097/00005768-199611000-00009] [PMID: 8933491]

[112] Gathercole RJ, Sporer BC, Stellingwerff T, Sleivert GG. Comparison of the Capacity of Different Jump and Sprint Field Tests to Detect Neuromuscular Fatigue. J Strength Cond Res 2015; 29(9): 2522-31. [http://dx.doi.org/10.1519/JSC.0000000000000912] [PMID: 26308829]

[113] Enoka RM, Duchateau J. Muscle fatigue: what, why and how it influences muscle function. J Physiol 2008; 586(1): 11-23. [http://dx.doi.org/10.1113/jphysiol.2007.139477] [PMID: 17702815]

[114] Delextrat A, Baker J, Cohen DD, Clarke ND. Effect of a simulated soccer match on the functional hamstrings-to-quadriceps ratio in amateur female players. Scand J Med Sci Sports 2013; 23(4): 478-86. [http://dx.doi.org/10.1111/j.1600-0838.2011.01415.x] [PMID: 22107131]

[115] Greig M. The influence of soccer-specific fatigue on peak isokinetic torque production of the knee flexors and extensors. Am J Sports Med 2008; 36(7): 1403-9.

[http://dx.doi.org/10.1177/0363546508314413] [PMID: 18326034]

[116] Small K, McNaughton L, Greig M, Lovell R. The effects of multidirectional soccer-specific fatigue on markers of hamstring injury risk. J Sci Med Sport 2010; 13(1): 120-5 [http://dx.doi.org/10.1016/j.jsams.2008.08.005] [PMID: 18976956]

[117] Rahnama N, Reilly T, Lees A, Graham-Smith P. Muscle fatigue induced by exercise simulating the work rate of competitive soccer. J Sports Sci 2003; 21(11): 933-42.

[http://dx.doi.org/10.1080/0264041031000140428] [PMID: 14626373]

[118] Warren GL, Lowe DA, Armstrong RB. Measurement tools used in the study of eccentric contraction-induced injury. Sports Med 1999; 27(1): 43-59. [http://dx.doi.org/10.2165/00007256-199927010-00004] [PMID: 10028132]

[119] Byrne C, Twist C, Eston R. Neuromuscular function after exercise-induced muscle damage: theoretical and applied implications. Sports Med 2004; 34(1): 49-69. [http://dx.doi.org/10.2165/00007256-200434010-00005] [PMID: 14715039]

[120] Rampinini E, Bishop D, Marcora SM, Ferrari Bravo D, Sassi R, Impellizzeri FM. Validity of simple field tests as indicators of match-related physical performance in top-level professional soccer players. Int J Sports Med 2007; 28(3): 228-35. [http://dx.doi.org/10.1055/s-2006-924340] [PMID: 17024621]

[121] Buchheit M, Haydar B, Ahmaidi S. Repeated sprints with directional changes: do angles matter? J Sports Sci 2012; 30(6): 555-62. [http://dx.doi.org/10.1080/02640414.2012.658079] [PMID: 22335343]

[122] Aziz AR, Mukherjee S, Chia MY, Teh KC. Relationship between measured maximal oxygen uptake and aerobic endurance performance with running repeated sprint ability in young elite soccer players. J Sports Med Phys Fitness 2007; 47(4): 401-7. [PMID: 18091678]

[123] da Silva JF, Guglielmo LG, Bishop D. Relationship between different measures of aerobic fitness and repeated-sprint ability in elite soccer players. J Strength Cond Res 2010; 24(8): 2115-21. [http://dx.doi.org/10.1519/JSC.0b013e3181e34794] [PMID: 20613644]

[124] Dupont G, Millet GP, Guinhouya C, Berthoin S. Relationship between oxygen uptake kinetics and performance in repeated running sprints. Eur J Appl Physiol 2005; 95(1): 27-34.

[http://dx.doi.org/10.1007/s00421-005-1382-8] [PMID: 15976999]

[125] Hughes M, Franks I. Analysis of passing sequences, shots and goals in soccer. J Sports Sci 2005; 23(5): 509-14. [http://dx.doi.org/10.1080/02640410410001716779] [PMID: 16194998]

[126] Russell M, Kingsley M. Influence of exercise on skill proficiency in soccer. Sports Med 2011; 41(7): 523-39. [http://dx.doi.org/10.2165/11589130-000000000-00000] [PMID: 21688867]

[127] Lyons M, Al-Nakeeb Y, Nevill A. Performance of soccer passing skills under moderate and high-intensity localized muscle fatigue. J Strength Cond Res 2006; 20(1): 197-202.

[PMID: 16503681]

[128] Eston RG, Williams JG. Reliability of ratings of perceived effort regulation of exercise intensity. Br J Sports Med 1988; 22(4): 153-5. [http://dx.doi.org/10.1136/bjsm.22.4.153] [PMID: 3228684]

[129] Borg G. Perceived exertion as an indicator of somatic stress. Scand J Rehabil Med 1970; 2(2): 92-8. [PMID: 5523831]

[130] Stoudemire NM, Wideman L, Pass KA, McGinnes CL, Gaesser GA, Weltman A. The validity of regulating blood lactate concentration during running by ratings of perceived exertion. Med Sci Sports Exerc 1996; 28(4): 490-5. 
[http://dx.doi.org/10.1097/00005768-199604000-00014] [PMID: 8778555]

[131] Ueda T, Kurokawa T. Relationships between perceived exertion and physiological variables during swimming. Int J Sports Med 1995; 16(6): $385-9$.

[http://dx.doi.org/10.1055/s-2007-973025] [PMID: 7591390]

[132] Yanci J, Martínez-Santos R, Los Arcos A. Respiratory and muscular perceived efforts after official games in professional soccer players. J Strength Cond Res 2014; 28: 11-45.

[133] Los Arcos A, Méndez-Villanueva A, Yanci J, Martínez-Santos R. Respiratory and Muscular Perceived Exertion During Official Games in Professional Soccer Players. Int J Sports Physiol Perform 2016; 11(3): 301-4.

[http://dx.doi.org/10.1123/ijspp.2015-0270] [PMID: 26217923]

[134] Gil-Rey E, Lezaun A, Los Arcos A. Quantification of the perceived training load and its relationship with changes in physical fitness performance in junior soccer players. J Sports Sci 2015; 33(20): 2125-32 [http://dx.doi.org/10.1080/02640414.2015.1069385] [PMID: 26222603]

[135] Hamilton AL, Killian KJ, Summers E, Jones NL. Quantification of intensity of sensations during muscular work by normal subjects. J Appl Physiol 1996; 81(3): 1156-61. [PMID: 8889748]

[136] Thorpe RT, Strudwick AJ, Buchheit M, Atkinson G, Drust B, Gregson W. Monitoring Fatigue During the In-Season Competitive Phase in Elite Soccer Players. Int J Sports Physiol Perform 2015; 10(8): 958-64.

[http://dx.doi.org/10.1123/ijspp.2015-0004] [PMID: 25710257]

[137] Saw AE, Main LC, Gastin PB. Monitoring the athlete training response: subjective self-reported measures trump commonly used objective measures: a systematic review. Br J Sports Med 2016; 50(5): 281-91. [http://dx.doi.org/10.1136/bjsports-2015-094758] [PMID: 26423706]

[138] Borresen J, Lambert MI. The quantification of training load, the training response and the effect on performance. Sports Med 2009; 39(9): 779-95.

[http://dx.doi.org/10.2165/11317780-000000000-00000] [PMID: 19691366]

[139] Williams AM. Perceptual skill in soccer: implications for talent identification and development. J Sports Sci 2000; 18(9): 737-50. [http://dx.doi.org/10.1080/02640410050120113] [PMID: 11043899]

[140] Greig M, Marchant D, Lovell R, Clough P, McNaughton L. A continuous mental task decreases the physiological response to soccer-specific intermittent exercise. Br J Sports Med 2007; 41(12): 908-13.

[http://dx.doi.org/10.1136/bjsm.2006.030387] [PMID: 17517858]

[141] Marcora SM, Staiano W, Manning V. Mental fatigue impairs physical performance in humans. J Appl Physiol 2009; 106(3): 857-64. [http://dx.doi.org/10.1152/japplphysiol.91324.2008] [PMID: 19131473]

[142] Lorist MM, Boksem MA, Ridderinkhof KR. Impaired cognitive control and reduced cingulate activity during mental fatigue. Brain Res Cogn Brain Res 2005; 24(2): 199-205.

[http://dx.doi.org/10.1016/j.cogbrainres.2005.01.018] [PMID: 15993758]

[143] Nederhof E, Lemmink KA, Visscher C, Meeusen R, Mulder T. Psychomotor speed: possibly a new marker for overtraining syndrome. Sports Med 2006; 36(10): 817-28. [http://dx.doi.org/10.2165/00007256-200636100-00001] [PMID: 17004845]

[144] Palacios G, Pedrero-Chamizo R, Palacios N, Maroto-Sánchez B, Aznar S, González-Gross M. Biomarkers of physical activity and exercise. Nutr Hosp 2015; 31(Suppl 3): 237-44.

[http://dx.doi.org/10.3305/nh.2015.31.sup3.8771] [PMID: 25719791]

[145] Heisterberg MF, Fahrenkrug J, Krustrup P, Storskov A, Kjær M, Andersen JL. Extensive monitoring through multiple blood samples in professional soccer players. J Strength Cond Res 2013; 27(5): 1260-71. [http://dx.doi.org/10.1519/JSC.0b013e3182653d17] [PMID: 22744299]

[146] Nikolaidis MG, Protosygellou MD, Petridou A, Tsalis G, Tsigilis N, Mougios V. Hematologic and biochemical profile of juvenile and adult athletes of both sexes: implications for clinical evaluation. Int J Sports Med 2003; 24(7): 506-11. [http://dx.doi.org/10.1055/s-2003-42014] [PMID: 12968208]

[147] Terrados N, Mora Rodríguez R, Padilla S. La recuperación de la fatiga del deportista. Madrid: Gymnos 2004.

[148] Peake JM, Suzuki K, Coombes JS. The influence of antioxidant supplementation on markers of inflammation and the relationship to oxidative stress after exercise. J Nutr Biochem 2007; 18(6): 357-71. [http://dx.doi.org/10.1016/j.jnutbio.2006.10.005] [PMID: 17156994]

[149] Bieuzen F, Bleakley CM, Costello JT. Contrast water therapy and exercise induced muscle damage: a systematic review and meta-analysis. PLoS One 2013; 8(4): e62356. [http://dx.doi.org/10.1371/journal.pone.0062356] [PMID: 23626806]

[150] Finsterer J. Biomarkers of peripheral muscle fatigue during exercise. BMC Musculoskelet Disord 2012; 13: 218 [http://dx.doi.org/10.1186/1471-2474-13-218] [PMID: 23136874]

[151] Gosker HR, Schols AM. Fatigued muscles in COPD but no finishing line in sight. Eur Respir J 2008; 31(4): 693-4. [http://dx.doi.org/10.1183/09031936.00015308] [PMID: 18378778] 
[152] Mayhew SR, Wenger HA. Time-motion analysis of professional soccer. J Hum Mov Stud 1985; 11(1): 49-52.

[153] Colombini A, Machado M, Lombardi G, Lanteri P, Banfi G. Modifications of biochemical parameters related to protein metabolism and renal function in male soccer players after a match. J Sports Med Phys Fitness 2014; 54(5): 658-64. [PMID: 25270786]

[154] Rico-Sanz J, Zehnder M, Buchli R, Dambach M, Boutellier U. Muscle glycogen degradation during simulation of a fatiguing soccer match in elite soccer players examined noninvasively by 13C-MRS. Med Sci Sports Exerc 1999; 31(11): 1587-93. [http://dx.doi.org/10.1097/00005768-199911000-00014] [PMID: 10589861]

[155] Meyer T, Meister S. Routine blood parameters in elite soccer players. Int J Sports Med 2011; 32(11): 875-81. [http://dx.doi.org/10.1055/s-0031-1280776] [PMID: 22020850]

[156] Siqueira L de O, Muccini T, Dall Agnol I, et al. Serum chemistry test and urinalysis parameter analysis in half marathon athletes. Arq Bras Endocrinol Metabol 2009; 53(7): 844-52. [http://dx.doi.org/10.1590/S0004-27302009000700008] [PMID: 19942986]

[157] Viru AA, Viru M. Biochemical monitoring of sport training. Champaign, IL: Human Kinetics 2001.

[158] Hübner E, Szmuchrowsky L, Lutoslawska G. Effects of soccer match-play on selected blood biochemical variables. Biol Sport 1994; 11(2): $83-9$.

[159] Hartmann U, Mester J. Training and overtraining markers in selected sport events. Med Sci Sports Exerc 2000; 32(1): 209-15. [http://dx.doi.org/10.1097/00005768-200001000-00031] [PMID: 10647551]

[160] Bangsbo J. Fitness training in football: a scientific approach. HO \& Storm, Bagsvaerd 1994.

[161] Meister S, Faude O, Ammann T, Schnittker R, Meyer T. Indicators for high physical strain and overload in elite football players. Scand J Med Sci Sports 2013; 23(2): 156-63. [http://dx.doi.org/10.1111/j.1600-0838.2011.01354.x] [PMID: 21812823]

[162] Handziski Z, Maleska V, Petrovska S, et al. The changes of ACTH, cortisol, testosterone and testosterone/cortisol ratio in professional soccer players during a competition half-season. Bratisl Lek Listy 2006; 107(6-7): 259-63. [PMID: 17051905]

[163] Arruda AF, Aoki MS, Freitas CG, Spigolon LM, Franciscon C, Moreira A. Testosterone Concentration and Lower Limb Power Over an Entire Competitive Season in Elite Young Soccer Players. J Strength Cond Res 2015; 29(12): 3380-5. [http://dx.doi.org/10.1519/JSC.0000000000000993] [PMID: 26595131]

[164] Koundourakis NE, Androulakis NE, Malliaraki N, Tsatsanis C, Venihaki M, Margioris AN. Discrepancy between exercise performance, body composition, and sex steroid response after a six-week detraining period in professional soccer players. PLoS One 2014; 9(2): e87803. [http://dx.doi.org/10.1371/journal.pone.0087803] [PMID: 24586293]

[165] Michailidis Y. Stress hormonal analysis in elite soccer players during a season. J Sport Health Sci 2014; 3(4): $279-83$. [http://dx.doi.org/10.1016/j.jshs.2014.03.016]

[166] Peñailillo L, Maya L, Niño G, Torres H, Zbinden-Foncea H. Salivary hormones and IgA in relation to physical performance in football. J Sports Sci 2015; 33(20): 2080-7.

[http://dx.doi.org/10.1080/02640414.2015.1064151] [PMID: 26146019]

[167] Gravina L, Ruiz F, Lekue JA, Irazusta J, Gil SM. Metabolic impact of a soccer match on female players. J Sports Sci 2011; $29(12)$ : 1345-52. [http://dx.doi.org/10.1080/02640414.2011.597420] [PMID: 21777165]

[168] Neave N, Wolfson S. Testosterone, territoriality, and the home advantage. Physiol Behav 2003; 78(2): 269-75. [http://dx.doi.org/10.1016/S0031-9384(02)00969-1] [PMID: 12576125]

[169] Oliveira T, Gouveia MJ, Oliveira RF. Testosterone responsiveness to winning and losing experiences in female soccer players. Psychoneuroendocrinology 2009; 34(7): 1056-64.

[http://dx.doi.org/10.1016/j.psyneuen.2009.02.006] [PMID: 19278791]

[170] Ekblom B. Assessment of fitness and player profiles. In: Dvorak J, Kirkendall D, Eds. Proceedings of the International Football and Sports Medicine Conference. Beverly Hills (CA). 2002; pp. 22-4.

[171] Filaire E, Lac G, Pequignot J-M. Biological, hormonal, and psychological parameters in professional soccer players throughout a competitive season. Percept Mot Skills 2003; $97(3$ Pt 2): 1061-72. [http://dx.doi.org/10.2466/pms.2003.97.3f.1061] [PMID: 15002848]

[172] De Vita F, Dorizzi R, Corradini G, Caruso B. Training and hormonal variability in a premier league soccer team. Proceedings of the 12th Annual Congress of the ECSS. Jyväskylä, Finland. 2007.

[173] Banfi G, Dolci A. Free testosterone/cortisol ratio in soccer: usefulness of a categorization of values. J Sports Med Phys Fitness 2006; 46(4): 611-6. [PMID: 17119528]

[174] Brentano MA, Martins Kruel LF. A review on strength exercise-induced muscle damage: applications, adaptation mechanisms and limitations. J Sports Med Phys Fitness 2011; 51(1): 1-10. [PMID: 21297557] 
[175] Hackney AC, Machado M. Hormonal status, creatine kinase and soccer: a need for research. Arq Bras Endocrinol Metabol 2012; 56(9): 683-5.

[http://dx.doi.org/10.1590/S0004-27302012000900014] [PMID: 23329194]

[176] Souglis AG, Papapanagiotou A, Bogdanis GC, Travlos AK, Apostolidis NG, Geladas ND. Comparison of inflammatory responses to a soccer match between elite male and female players. J Strength Cond Res 2015; 29(5): 1227-33. [http://dx.doi.org/10.1519/JSC.0000000000000767] [PMID: 25436628]

[177] Lazarim FL, Antunes-Neto JM, da Silva FO, et al. The upper values of plasma creatine kinase of professional soccer players during the Brazilian National Championship. J Sci Med Sport 2009; 12(1): 85-90.

[http://dx.doi.org/10.1016/j.jsams.2007.10.004] [PMID: 18069060]

[178] Baldwin Lanier A. Use of nonsteroidal anti-inflammatory drugs following exercise-induced muscle injury. Sports Med 2003; $33(3)$ : $177-85$. [http://dx.doi.org/10.2165/00007256-200333030-00002] [PMID: 12656639]

[179] Bessa AL, Oliveira VN, Agostini GG, et al. Exercise intensity and recovery: Biomarkers of injury, inflammation and oxidative stress. J Strength Cond Res 2016; 30(2): 311-9.

[http://dx.doi.org/10.1519/JSC.0b013e31828f1ee9] [PMID: 23604000]

(C) 2017 Marqués-Jiménez et al.

This is an open access article distributed under the terms of the Creative Commons Attribution 4.0 International Public License (CC-BY 4.0), a copy of which is available at: https://creativecommons.org/licenses/by/4.0/legalcode. This license permits unrestricted use, distribution, and reproduction in any medium, provided the original author and source are credited. 